\title{
VEGETATION-BASED LANDSCAPE REGIONS OF HUNGARY
}

\author{
CS. MOLNÁR ${ }^{1}$, ZS. MOLNÁR ${ }^{1}$, Z. BARINA ${ }^{2}$, N. BAUER ${ }^{2}$, M. BIRÓ ${ }^{1}$, L. BODONCZI ${ }^{3}$, \\ A. I. CSATHÓ ${ }^{4}$, J. CSIKY ${ }^{5}$, J. Á. DEÁK ${ }^{6}$, G. FEKETE ${ }^{1}$, K. HARMOS $^{7}$, A. HORVÁTH ${ }^{1}$, I. ISÉPY ${ }^{8}$, \\ M. JuHÁsZ ${ }^{9}$, J. KÁlLAYNÉ SZERÉNYI ${ }^{10}$, G. KIRÁLY ${ }^{11}$, G. MAGOS ${ }^{7}$, A. MÁTÉ ${ }^{12}$, \\ A. MESTERHÁZY ${ }^{11}$, A. MOLNÁR ${ }^{13}$, J. NAGY ${ }^{14}$, M. ÓVÁRI ${ }^{15}$, D. PURGER ${ }^{16}$, D. SCHMIDT ${ }^{5}$, \\ G. SRAMKÓ ${ }^{17}$, V. SZÉNÁSI ${ }^{18}$, F. SZMORAD ${ }^{19}$, GY. SZOLLÁT ${ }^{20}$, T. TÓTH ${ }^{21}$, T. VIDRA ${ }^{18}$, \\ and V. VIRÓK ${ }^{19}$ \\ ${ }^{1}$ Institute of Ecology and Botany of the Hungarian Academy of Sciences \\ H-2163 Vácrátót, Alkotmány u. 2-4, Hungary \\ E-mail:birkaporkolt@yahoo.co.uk; molnar@botanika.hu \\ ${ }^{2}$ Department of Botany, Hungarian Natural History Museum \\ H-1476 Budapest, Könyves K. krt 40, Hungary \\ ${ }^{3}$ Kakasmandikó Bt., H-9941 Öriszentpéter, Alszer 28/A, Hungary \\ ${ }^{4} \mathrm{H}-5830$ Battonya, Somogyi Béla u. 42/A, Hungary \\ ${ }^{5}$ Department of Plant Taxonomy and Geobotany, University of Pécs \\ H-7600 Pécs, Ifjúság útja 6, Hungary \\ ${ }^{6}$ Department of Climatology and Landscape Ecology, University of Szeged \\ H-6701 Szeged, Pf. 653, Hungary \\ ${ }^{7}$ Bükk National Park Directorate, H-3304 Eger, Sánc u. 6, Hungary \\ ${ }^{8}$ Botanical Garden of Eötvös Loránd University, H-1083 Budapest, Illés u. 25, Hungary \\ ${ }^{9}$ Natural History Department, Somogy County Museum, H-7401 Kaposvár, Fö u. 10, Hungary \\ ${ }^{10}$ Department of Plant Taxonomy and Ecology, Eötvös Loránd University \\ H-1117 Budapest, Pázmány P. sétány 1/C, Hungary \\ ${ }^{11}$ Department of Botany, University of West Hungary, H-9400 Sopron, Pf. 132, Hungary \\ ${ }^{12}$ Kiskunság National Park Directorate, H-6000 Kecskemét, Liszt F. u. 19, Hungary \\ ${ }^{13}$ Hortobágy National Park Directorate, H-4024 Debrecen, Sumen u. 2, Hungary \\ ${ }^{14}$ Department of Botany, Corvinus University of Budapest \\ H-1118 Budapest, Ménesi út 44, Hungary \\ ${ }^{15}$ Balatoni National Park Directorate, H-8229 Csopak, Kossuth utca 16, Hungary \\ ${ }^{16}$ Department of Animal Ecology, University of Pécs, H-7624 Pécs, Ifjúság útja 6, Hungary \\ ${ }^{17}$ Department of Botany, University of Debrecen, H-4010 Debrecen, Pf. 14, Hungary \\ ${ }^{18}$ Duna-Ipoly National Park Directorate, H-1021 Budapest, Hüvösvölgyi út 52, Hungary \\ ${ }^{19}$ Aggtelek National Park Directorate, H-3758 Jósvafó, Tengerszem oldal 1, Pf. 6, Hungary \\ ${ }^{20} \mathrm{H}-1028$ Budapest, Máriaremetei út 54, Hungary \\ ${ }^{21}$ Körös-Maros National Park Directorate, H-5540 Szarvas, Anna-liget 1, Hungary
}

(Received 1 August, 2008; Accepted 5 November, 2008)

The first version of the map of the Hungarian vegetation-based landscape regions were prepared at the scale of $1: 200,000$ (1 km or higher resolution). The primary goal of the map was to provide an exact background for the presentation and evaluation of the data of the MÉTA database. Secondly, we intended to give an up-to-date and detailed vegetation-based division of Hungary with a comprehensive nomenclature of the regions. Regions were primar- 
ily defined on the basis of their present zonal vegetation, or their dominant extrazonal or edaphic vegetation. Where this was not possible, abiotic factors that influence the potential vegetation, the flora were taken into consideration, thus, political and economical factors were ignored. All region borders were defined by local expert botanists, mainly based on their field knowledge. The map differs in many features from the currently used, country-wide, flora- or geography-based divisions in many features. We consider our map to be temporary (i.e. a work map), and we plan to refine and improve it after 5 years of testing.

Key words: botanical map, classifying by vegetation, Hungary, natural vegetation, phytogeography

\section{INTRODUCTION}

The division of Hungary into landscape regions have already been prepared by many authors from different point of views (e.g. pedological, public service, ethnographical, silvicultural, see Pécsi 1989) and at different scales. Although, botanical divisions are also available, these are either confined to local areas (e.g. certain mountains) or based mainly on floristic data. For botanical studies, the most frequently used division is the inventory of the physical geographical microregions of Hungary (Keresztesi et al. 1989, Marosi and Somogyi 1990), because of its relatively high resolution and country-wide completeness. The silvicultural division of Hungary combines geographical (site-conditions), vegetational (forest-types) and forest management (borders of forestry districts) factors (Babos 1954), but more recently, a solely geography-based division was also prepared (Halász 2006). Regarding its methodology and results, this map is similar to the one presented in this paper. Zoogeographical maps were also drawn based mainly on geographical and botanical features beside the zoological ones (e.g. Soós 1934, Kolosváry 1936, Varga 1964, Mándy 1989).

Botanical division of Hungary into phytogeographical landscape units dates back to the end of the 19th century. The work of Borbás (1905), Simonkai (published by Tuzson 1910) and Tuzson (1911) should be mentioned. The first comprehensive map was prepared by Jávorka (1925) and Rapaics (1927), and this was modified and unified by Zólyomi (1951) and Soó (1941, 1960, 1961, 1964). Until now, most authors use the work of Soó (1964), or its later versions (e.g. Pócs 1981, Molnár 1999). Floristics always played a major role in Hungarian phytogeography, perhaps because of the influence of Rezső Soó and the special botanical characteristics of the Carpatho-Pannonian Region, thus the phytogeographical landscape divisions were all based on floristic data, and they divided the country into flora regions and flora subregions. On the other hand, many fine scale vegetation maps were merged by Zólyomi $(1967,1989)$ 
into a map of the natural vegetation of Hungary. Since it was not amongst its goals, the map did not delimit vegetation regions, as did neither other large scale synthetic works (e.g. Niklfeld 1973, Isachenko and Lavrenko 1974, Michalko et al. 1987, Ivan et al. 1993, Bohn et al. 2000-2003). Flora- and vegetation-based delimitations could be combined by regarding vegetation zones as landscape regions (e.g. the beech zone or the Quercus cerris zone could form one region in the Északi-középhegység (Fekete 1998, Vojtkó ex verb.), but such a map has never been prepared. Few years ago, a work team of botanists led by Sándor Farkas attempted to refine the microregion borders of Marosi and Somogyi (1990) for the proper localisation and analysis of floristic data (Farkas 2001-2005). This map (the preparation has not finished yet) drove the attention of many botanists to the need of a new phytogeographical division, so it can be considered as the most important antecedent of the map presented here.

\section{METHODS}

The resolution of the map was set partly arbitrary, since we planned to produce a map with approx. 100 regions. This is a scale between the physical geographical micro- and mesoregions (Marosi and Somogyi 1990). The borders were drawn with at least $1 \mathrm{~km}$ accuracy (scale ca $1: 200,000)$. All regions were delimited based on its vegetation, we looked for repetitive vegetation complexes (zonal vegetation, or the dominant extrazonal and edaphic vegetation). Where no natural vegetation survived or recent fragments differ significantly from the natural vegetation (e.g. only water-fringing vegetation remained in a once wooded landscape), the potential vegetation was considered. Floristic composition and abiotic factors (e.g. geology, climate) were taken only secondarily into consideration. We did not consider economical (e.g. roads, canals) and political factors (e.g. state and county borders of Hungary) factors. This resulted in some small regions that cross the country border, and only small parts lie in Hungary (e.g. "Vendvidék" vegetation-based landscape region, "Maros-ártér" vegetation-based landscape region, "Érmellék" vegetation-based landscape region). The division of the whole Pannonicum into vegetation-based landscape regions remained a future task. Regions made up of two or more parts were only formed if it was absolutely necessary (e.g. the basalt inselbergs ("Szent György-hegy" and "Szigliget") of "Balaton-felvidék" or the "Tihanyi-félsziget").

All borders were defined by local expert botanists, mainly based on their field knowledge. Other background information was rarely used, so our map is not a database derived one. For the exact localisation of the borders, the following maps were used: topographical maps, altitudinal maps, satellite im- 
ages, pedological maps (Agrotopo, Várallyay 1985, Szabó et al. 2005), and additionally, in certain cases, historical maps, climatic data and habitat data from the MÉTA database were also used. Some recently published maps and studies (Vojtkó 2001, Bodonczi 2005, Király et al. 2007, Deák 2008, Schmidt et al. 2008) were also used.

Since the map is a co-operational work of many botanists, certainly, it comes with heterogeneity. Albeit we tried to apply a uniform algorithm (at least at the physical geographical macroregion level), this could not be fully reached. We accept that there are only few sharp borders in nature so the region borders on the map - in most cases - in fact are transitional zones with variable width.

The borders of regions were often based on elevation above see level (e.g. border between "Dráva-sík" and "Mecsek" mountains, or between "MagasMátra" and "Déli-Mátra", or between "Hegyalja" and "Harangod és Hernádmagaspart"), or on a significant altitudinal lift (e.g. border between "Baranyai-dombság" and "Duna-völgy"; border between "Harangod és Hernádmagaspart" and "Sajó és Hernád völgye"). On the lowlands geomorphology of the floodplains were consequently used for delimiting the great river valleys (e.g. along the Tisza and Duna). Geological differences in the mountains (e.g. "Északi-Cserhát" and "Központi-Cserhát", "Visegrádi-hegység" and "Pilis, Budai-hegység") and soil pattern on the lowlands (e.g. "Észak-Nyírség" and "Dél-Nyírség", "Felső-Bácska" and "Homokhátság", "Mosoni-sík" and "Hanság") also played an important role.

Many difficulties were faced during the delimitation of the regions. Firstly, the division of certain areas can be made in different ways, due partly to the different views of the local experts, partly to the characterless, secondary actual vegetation, and partly also to the wide continuous transitions. This is the case in the regions "Örség" and "Vasi-, Zalai-hegyhát és Kemeneshát". These regions could have been merged, but their size and the East-West gradient through them argued for separating them into two regions. The border of these regions, however, could have been drawn elsewhere, more to the East. In many cases the vegetation between two distinctive regions became as much degraded and characterless as we could attach this transitional land to either region. This is specifically true for lower hilly regions between mountains, where the above-mentioned phenomenon is strengthened by natural factors (e.g. rarity of extreme habitats, stronger influence of macroclimate). The attachment of small sized transitions to a certain region was the decision of the local experts (see e.g. the borders of "Karancs és Medves"). We endeavoured to avoid the use of river valleys as borders, since rivers rather connect landscapes than separate. So, their valleys were either separated as a distinct unit (e.g. "Rába-völgy", “Tisza-völgy", "Sajó- és Hernád-völgy"), or they were at- 
tached to the neighbouring region (e.g. the "Zala-völgy" to the "Zalai-dombság" region; the "Sió-völgy" to the "Nyugat-Mezőföld"; the valleys of Zagyva and Tarna to the "Tápió-Sajó hordalékkúp síkság"). The delimitation was in many cases hampered by the complete lack of natural vegetation. The region borders in these cases were drawn with some inaccuracy and difficulty (e.g. "Maros-Körös köze" and the eastern part of the "Berettyó-Körös-vidék"). In many cases, we faced the problem of delimitation of areas where the region was characteristically different from its neighbours, but the size of the region was below the aimed scale. These areas were either treated as separate units (like the "Fertőmelléki-dombsor", or "Velencei-hegység"), or they were by necessity attached to a neighbouring region (e.g. the "Vindornya" mire was attached to the "Balaton-vidék" region). In one case, again by necessity, several small sized, but quite different regions were grouped together to form a heterogeneous region, the "Észak-Mezőföld".

The nomenclature of the vegetation-based landscape regions, whenever it was possible, followed the traditional nomenclature (e.g. "Ipoly-völgy" vegetation-based landscape region, "Vendvidék" vegetation-based landscape region, "Hanság" vegetation-based landscape region) or was derived from the traditional name (e.g. "Göcsej és Hetés" vegetation-based landscape region, "Észak-Nyírség", "Sárvíz- és Sió-völgy"). However, in certain cases the region borders did not fit to any traditional regions, so we had to create new names (e.g. "Szegedi-sík" vegetation-based landscape region, "Maros-ártér" vegetation-based landscape region) with careful respect to the regulations of the Hungarian geographical literature (Kádár 1941). All disconnected parts of a multi-segmented region were separately named and coded (e.g. the three parts of "Alpokaljai hegyek" are "Soproni-hegység", "Kőszegi-hegység" and "Vas-hegy"). There are three cases where only a very small part of a region lies in the territory of Hungary. We suggest evaluating these small regions as part of a neighbouring, similar region during future analysis.

\section{RESULTS AND DISCUSSION}

The map of the Hungarian vegetation-based landscape regions is shown in Figure 1, the nomenclature of the vegetation-based landscape regions in Table 1 .

The map differs from the currently used, country-wide, but flora-based botanical divisions (Soó 1964, Molnár 1999) in many features. Compared to the flora regions our map considers the "Lake Balaton", and the "Marcal-medence". The whole "Eszak-Mezóség" is not classified under the Bakonyicum flora region ("Dunántúli-középhegység"). The "Kisalföld" flora subregion (Arra- 


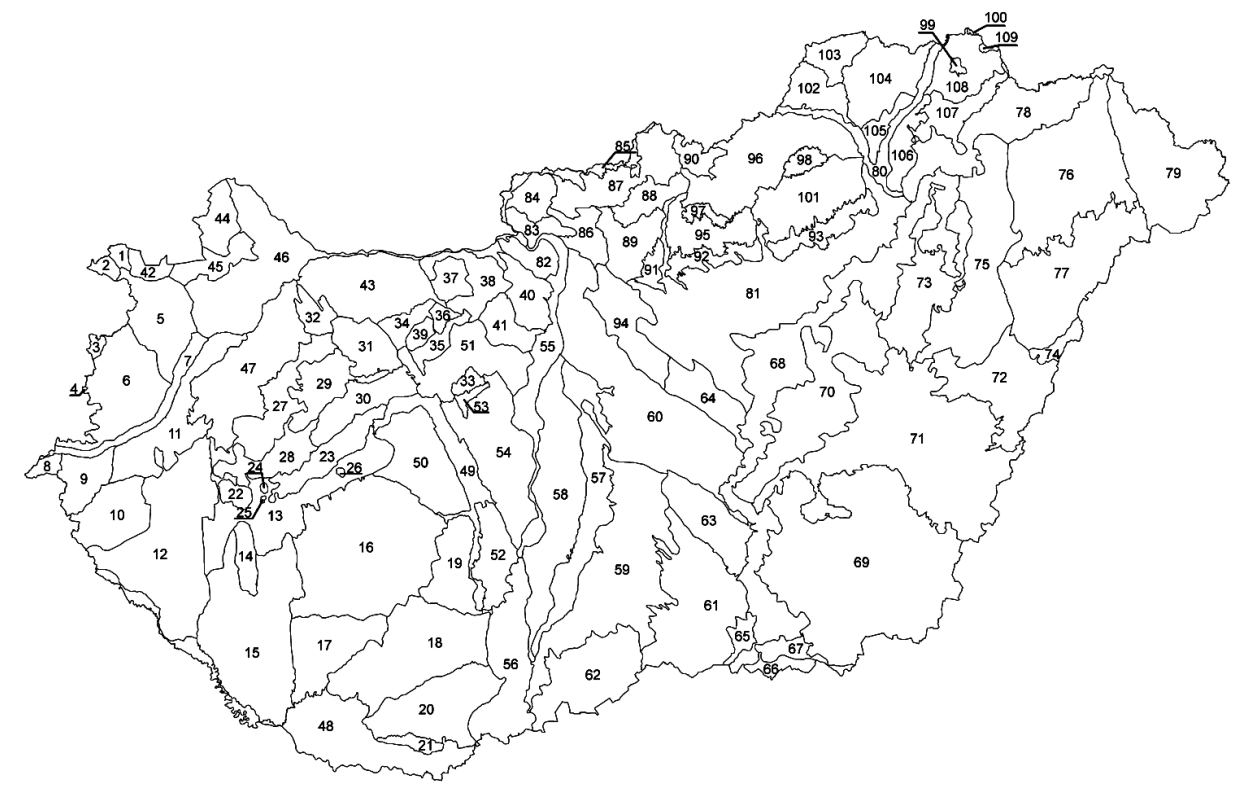

Fig. 1. The map of Hungarian vegetation-based landscape regions

Table 1

Names and authors of vegetation-based landscape regions

\begin{tabular}{|c|c|c|c|}
\hline $\begin{array}{l}\text { Geographical } \\
\text { macroregions }\end{array}$ & $\begin{array}{l}\text { Vegetation-based landscape } \\
\text { regions }\end{array}$ & Subregions & ID Authors \\
\hline \multirow[t]{13}{*}{ Nyugat-Dunántúl } & Fertőmelléki-dombsor & & $1 \mathrm{KG}$ \\
\hline & Alpokaljai hegyek & Soproni-hegység & $2 \mathrm{KG}$ \\
\hline & & Kőszegi-hegység & $3 \mathrm{KG}$ \\
\hline & & Vas-hegy & $4 \mathrm{KG}$ \\
\hline & Répce- and Ikva-sík & & $5 \mathrm{KG}$ \\
\hline & Gyöngyös- and Pinka-sík & & $6 \mathrm{KG}, \mathrm{BL}, \mathrm{MeA}$ \\
\hline & Rába-völgy & & $7 \mathrm{KG}, \mathrm{BL}, \mathrm{MeA}$ \\
\hline & Vendvidék & & $8 \mathrm{BL}$ \\
\hline & Őrség & & 9 BL, MeA \\
\hline & Göcsej and Hetés & & 10 ÓM, Bl \\
\hline & Vasi- and Zalai-hegyhát, & & \\
\hline & Kemeneshát & & $\begin{array}{l}11 \text { MeA, BL, ÓM, } \\
\text { KG }\end{array}$ \\
\hline & Zalai-dombság & & 12 ÓM, JM \\
\hline \multirow[t]{5}{*}{ Dél-Dunántúl } & Balaton-vidék & & $\begin{array}{l}13 \text { BN, JM, HA, } \\
\text { ÓM }\end{array}$ \\
\hline & Marcali-hát & & $14 \mathrm{JM}$ \\
\hline & Belső-Somogy & & $15 \mathrm{JM}$ \\
\hline & Külső-Somogy & & $16 \mathrm{JM}, \mathrm{HA}$ \\
\hline & Zselic & & $17 \mathrm{Jm}, \mathrm{CsJ}$ \\
\hline
\end{tabular}


Table 1 (continued)

\begin{tabular}{|c|c|c|c|c|}
\hline $\begin{array}{l}\text { Geographical } \\
\text { macroregions }\end{array}$ & Vegetation-based landscape region & sSubregions & ID & Authors \\
\hline \multirow[t]{5}{*}{ Dél-Dunántúl } & Mecsek, Völgység, & & & \\
\hline & Szekszárdi-dombság & & 18 & CsJ, JM, PD \\
\hline & Tolnai-dombság & & 19 & CsJ, HA, JM \\
\hline & Baranyai-dombság & & 20 & CsJ, PD \\
\hline & Villányi-hegység & & 21 & CsJ \\
\hline \multirow{22}{*}{$\begin{array}{l}\text { Dunántúli-közép- } \\
\text { hegység }\end{array}$} & Keszthelyi-hegység & & 22 & BJ, BN, ÓM \\
\hline & Balaton-felvidék & Balaton-felvidék & & \\
\hline & & (central part) & 23 & $\mathrm{BN}$ \\
\hline & & Szent György-hegy & 24 & $\mathrm{BN}$ \\
\hline & & Szigliget & 25 & $\mathrm{BN}$ \\
\hline & & Tihany & 26 & $\mathrm{BN}$ \\
\hline & Nyugati-Bakonyalja & & 27 & $\mathrm{BN}, \mathrm{MeA}$ \\
\hline & Déli-Bakony & & 28 & $\mathrm{BN}$ \\
\hline & Belső-Bakony & & 29 & $\mathrm{BN}, \mathrm{BJ}$ \\
\hline & Keleti-Bakony & & 30 & $\mathrm{BN}, \mathrm{BJ}$ \\
\hline & Központi-Bakonyalja & & 31 & $\mathrm{BN}, \mathrm{BJ}$ \\
\hline & Pannonhalmi-dombság & & 32 & SchD, BN \\
\hline & Velencei-hegység & & 33 & $\mathrm{BJ}, \mathrm{BN}$ \\
\hline & Bársonyos & & 34 & $\mathrm{BZ}$ \\
\hline & Dél-Vértes & & 35 & $\mathrm{BZ}, \mathrm{BN}$ \\
\hline & Vértes and Gerecse & Északi-Vértes & & \\
\hline & & (eastern part) & 36 & BZ \\
\hline & & Központi-Gerecse & 37 & BZ \\
\hline & Keleti-Gerecse & & 38 & $\mathrm{BZ}$ \\
\hline & Északi-Vértes (western part) & & 39 & BZ \\
\hline & Pilis, Budai-hegység & & 40 & BJ \\
\hline & Zsámbéki-medence és környéke & & 41 & KSzJ, BZ \\
\hline \multirow[t]{6}{*}{ Kisalföld } & Fertő-medence & & 42 & KG \\
\hline & $\begin{array}{l}\text { Győr-Tatai-teraszvidék and } \\
\text { Igmánd-Kisbéri-sík }\end{array}$ & & 43 & $\mathrm{KG}, \mathrm{SchD}, \mathrm{BN}$ \\
\hline & Mosoni-sík & & 44 & KG \\
\hline & Hanság & & 45 & KG \\
\hline & Kisalföldi Duna-völgy & & 46 & $\mathrm{KG}, \mathrm{BZ}, \mathrm{NJ}$ \\
\hline & Marcal-medence & & 47 & MeA, ÓM \\
\hline \multirow[t]{12}{*}{ Alföld } & Dráva-sík & & 48 & CsJ, JM, ÓM, PD \\
\hline & Sárvíz- and Sió-völgy & & 49 & $\mathrm{HA}$ \\
\hline & Nyugat-Mezőföld & & 50 & HA, BZ, JM \\
\hline & Észak-Mezőföld & & 51 & HA, BZ. KSzJ \\
\hline & Dél-Mezőföld & & 52 & HA \\
\hline & Velencei-tó & & 53 & $\mathrm{HA}, \mathrm{KSzJ}$ \\
\hline & Kelet-Mezőföld & & 54 & $\mathrm{HA}, \mathrm{KSzJ}$ \\
\hline & Közép-Duna-völgy & & 55 & $\begin{array}{l}\text { BM, HA, KSzJ, } \\
\text { NJ }\end{array}$ \\
\hline & Alsó-Duna-völgy & & 56 & $\mathrm{BM}, \mathrm{CsJ}, \mathrm{HA}$ \\
\hline & Örjeg & & 57 & MáA, BM \\
\hline & Duna-sík & & 58 & BM, MáA \\
\hline & Homokhátság & & & $\begin{array}{l}\text { BM, DJÁ, MáA, } \\
\text { CsAI }\end{array}$ \\
\hline
\end{tabular}


Table 1 (continued)

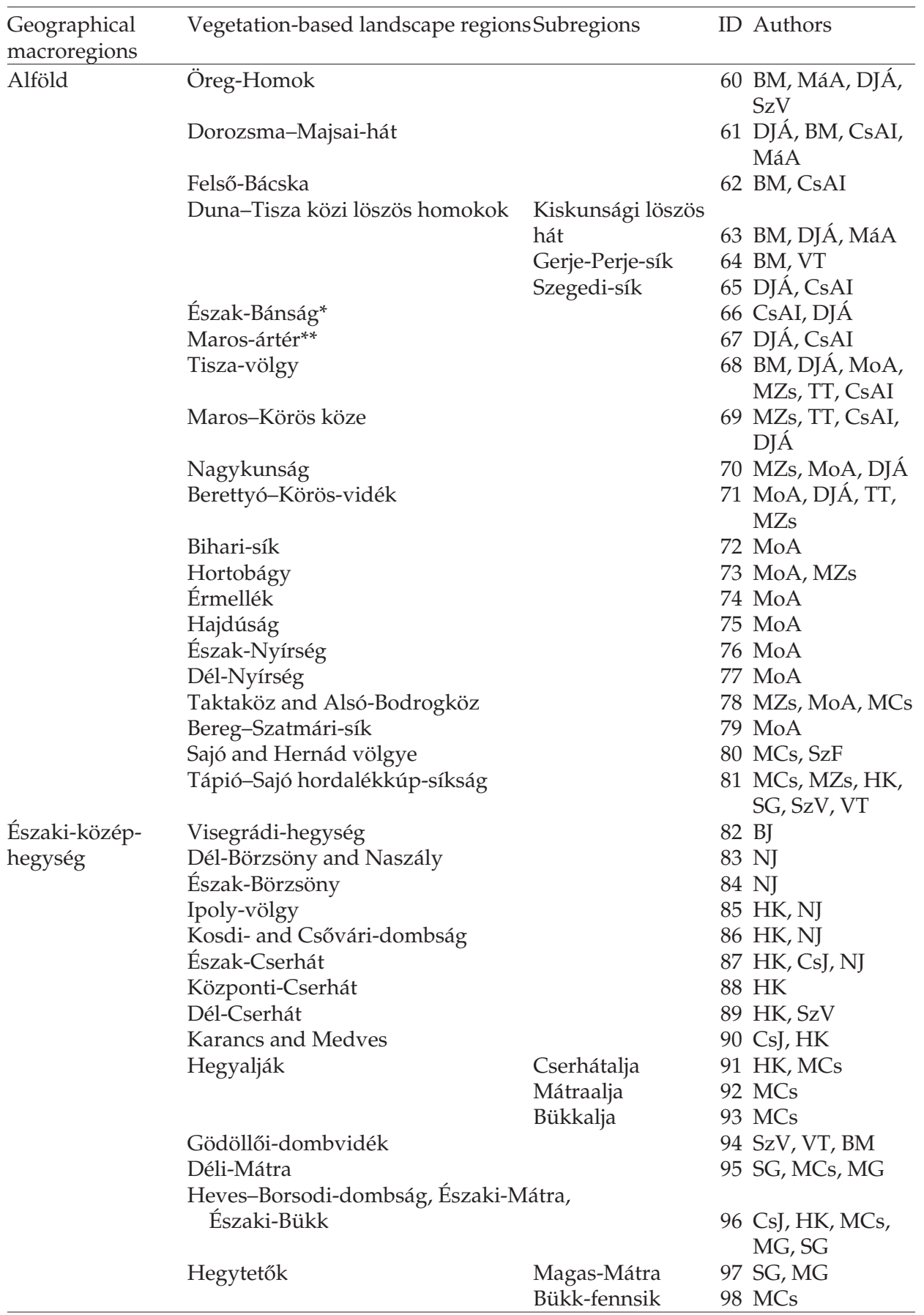


Table 1 (continued)

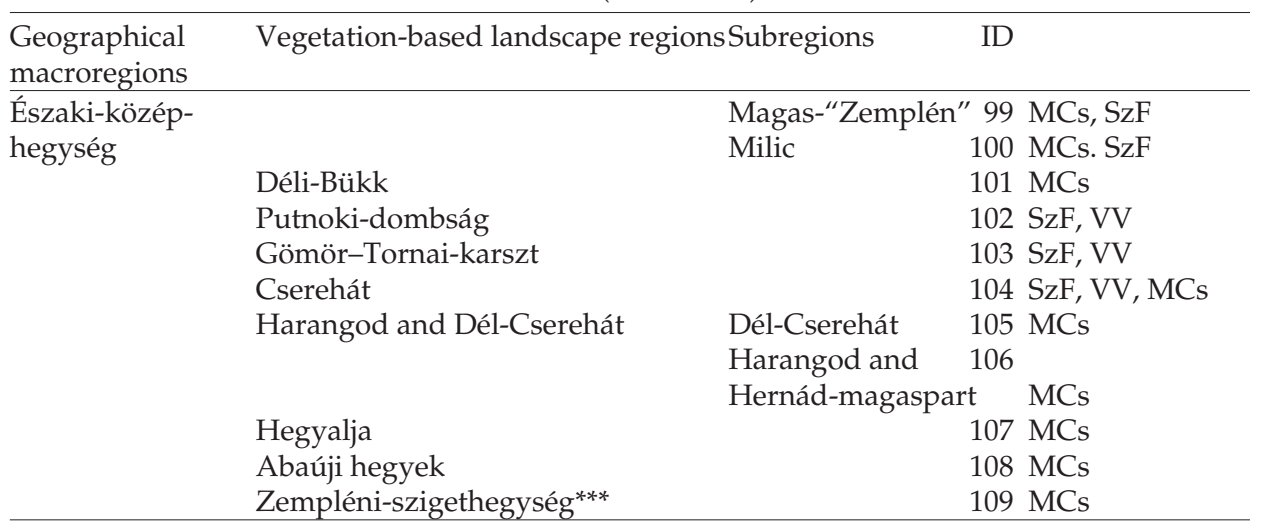

* = 66 "Észak-Bánság" in analyses can be merged to 69 "Maros-Körös köze"

** $=67$ "Maros-ártér" in analyses can be merged to 68 "Tisza-völgy"

*** $=109$ "Zempléni-szigethegység" in analyses can be merged to 107 "Hegyalja"

Authors: $\mathrm{BZ}=$ Zoltán Barina, $\mathrm{BN}=$ Norbert Bauer, $\mathrm{BM}=$ Marianna Biró, $\mathrm{BL}=$ László Bodonczi, BJ = János Bölöni, CsAI = András István Csathó, CsJ = János Csiky, DJÁ = Áron Deák József, HK = Krisztián Harmos, HA = András Horváth, JM = Magdolna Juhász, KSzJ = Júlia Kállayné Szerényi, KG = Gergely Király, MG = Gábor Magos, MáA = András Máté, MeA = Attila Mesterházy, MoA = Attila Molnár, MCs = Csaba Molnár, MZs = Zsolt Molnár, NJ = József Nagy, ÓM = Miklós Óvári, PD = Dragica Purger, SchD = Dávid Schmidt, SG = Gábor Sramkó, SzV = Valentin Szénási, SzF = Ferenc Szmorad, TT = Tamás Tóth, VT = Tamás Vidra, VV = Viktor Virók

bonicum) is divided into 5 vegetation-based landscape regions. Similarly, the traditional division unites the "Zalai-dombság", Tapolca and Kál Basins with "Bakonyalja" region (Saladiense), these are separate vegetation-based landscape regions. The traditional approach almost regularly cuts the "Északi-középhegység" into parts along its West-East axis, in contrast, our map tries to connect this pattern to altitudinal vegetation zones and edaphic vegetation features.

Grouping the vegetation-based landscape regions into six groups (according to the physical geographical macroregions, Marosi and Somogyi 1990), the fit is almost perfect. In fact, our map is a more precise version of the geographical regions. Differences are almost negligible (e.g. the river valleys protruding into the "Északi-középhegység" from the "Alföld" [namely "Zagyva" and "Sajó and Hernád" vegetation-based landscape regions], and the "Dráva-sík" vegetation-based landscape region intruding into "Dél-Dunántúl"). The new map treats some transitional regions, which are traditionally divided in geographical literature as separate unit, like the "Észak-Mezőföld", which links the "Alföld" to the "Dunántúli-középhegység" (the geographical division might intend to avoid the separation of "Velencei-hegység" as an is- 
land). Similarly, we classified separately some regions that lie in the foreground of the "Északi-középhegység", namely the vegetation-based landscape regions "Cserhátalja", "Mátraalja”, "Bükkalja”, "Harangod and Dél-Cserehát". When compared to the geographical mesoregions, the differences are more conspicuous, since the theoretical background of the divisions is quite different (see e.g. the "Bükk" and "Mátra" mountain regions).

The present map is not considered to be a final version. Both future field studies and the analysis of the MÉTA database will possibly introduce changes, refinements. The collaborators of this map intend to make a revised version of the map after five years of testing.

Acknowledgements - We express our thankfulness for our reviewer, Prof. Dr Dénes Bartha, for his inspiriting comments on the manuscript. We would like to thank the Jedlik Ányos Program for supporting project of "Interaction of natural and man-made ecosystems: landscape ecological studies of biodiversity and ecosystem functions in the Great Hungarian Plain, 2005-2008" (NKFP 6-0013/2005).

\section{REFERENCES}

Babos, I. (1954): Magyarország táji erdőmüvelésének alapjai. [Principles of landscape-based forest management]. - Mezőgazdasági Kiadó, Budapest, 164 pp.

Bodonczi, L. (2005): Javaslat Vas megye új, botanikai szempontú tájfelosztására. (Proposal for landscape division of Vas County according to new, botanical aspects). - Vasi Szemle 59(3): 356-378.

Bohn, U., Neuhäusl, R., Gollub, G., Hettwer, C., Neuhäuslová, Z., Raus, Th., Schlüter, H. and Weber, H. (eds) (2000-2003): Karte der natürlichen Vegetation Europas. 1:2500000. (Map of the natural vegetation of Europe). - Landwirtschaftsverlag, Münster.

Borbás, V. (1905): Magyarország természetes flórájának tagozódása. [Die Gliederung der natürlichen Flora Ungarns]. - In: György, E. (ed.): A Föld és népei V. Franklin Társulat Kiadása, Budapest, pp. 99-127.

Deák, J. Á. (2008): A tiszántúli flórajárás aktuális élőhelymintázatának felhasználása Csongrád megye kistájainak lehatárolásához. [The use of present habitat-pattern of Crisicum in determining borders of microregions of Csongrád county]. - Kitaibelia 13(1): 103.

Farkas, S. (ed.) (2001-2005): Magyarország kistájainak florisztikai szempontú lehatárolása. [Floristic delimitation of Hungary's microregions]. - Paks. (mscr.)

Fekete, G. (1998): Javaslat új típusú vegetációmonográfiák megalkotására. [Advices for the authors of new vegetation monographs]. - Kitaibelia 3(1): 71-73.

Halász, G. (ed.) (2006): Magyarország erdészeti tájai. [Forest regions of Hungary]. - Állami Erdészeti Szolgálat, Budapest, 154 pp.

Isachenko, T. I. and Lavrenko, E. M. (eds) (1974): Karta rastitelnosty Evropicheskiy chasty SSSR m-ba 1: 2500000. [Vegetation map of the European part of the USSR at scale 
1:2,500,000]. - Akademik Nauk, SSSR, Botanichesky Institute imeni V. L. Komarova. List 6.

Ivan, D., Donita, G., Coldea, G., Sanda, V., Popescu, A., Chifu, T., Boscaiu, N., Mititelu, D. and Pauca-Comanescu, M. (1993): Vegetation potentielle de la Roumanie. - BraunBlanquetia 9: 1-80.

Jávorka, S. (1925): Növényföldrajzi alapfogalmakés növényföldrajzi beosztás. [Fundamental concepts in phytogeography and phytogeographical division]. - In: Jávorka, S.: Magyar Flóra. Studium, Budapest, pp. LXXII-XCII.

Kádár, L. (1941): A magyar nép tájszemlélete és Magyarország tájnevei. [Attitude of Hungarian people to the landscape and landscape nomenclature in Hungary]. - A magyar táj- és népismeret könyvtára, Országos Táj- és Népkutató Intézet, Budapest, 26 pp.

Keresztesi, Z., Marosi, S., Pécsi, M. and Somogyi, S. (1989): Természeti tájak rendszertani felosztása. 1:1000000. [Taxonomic distribution of natural landscape units]. - In: Pécsi, M. (ed.): Magyarország Nemzeti Atlasza. MTA Földrajztudományi Kutató Intézete, Budapest, pp. 86-87.

Király, G., Mesterházy, A. and Király, A. (2007): Adatok a Nyugat-Dunántúl flórájához és növényföldrajzához. (Data to the knowledge of the flora and geobotany of West Transdanubia (W Hungary)). - Flora Pannonica 5: 3-66.

Kolosváry, G. (1936): Ein Versuch zur Einteilung der Karpathischen Länder mit Berücksichtigung der spinnenfaunistischen Angaben und ein Beitrag zum Rassenkreisproblem bei Spinnen. - Folia Zool. et Hydrobiol. 9: 92-114.

Mándy, Gy. (1989): Állatföldrajzi beosztás. [Zoogeographical division]. - In: Pécsi, M. (ed.): Magyarország Nemzeti Atlasza. MTA Földrajztudományi Kutató Intézete, Budapest, p. 88.

Marosi, S. and Somogyi, S. (eds) (1990): Magyarország kistájainak katasztere I-II. (Inventory of the physical geographical microregions of Hungary I-II). - MTA Földrajztudományi Kutató Intézet, Budapest.

Michalko, J., Magic, D., Berta, J., Rybníček, K. and Rybníčková, E. (1987): Geobotanical map of C.S.S.R. Slovak Socialist Republic. Text part. - Veda, Bratislava, 168 pp.

Molnár, V. A. (1999): Hazánk florisztikai beosztása. [Floristic division of Hungary]. - In: Farkas, S. (ed.): Magyarország védett növényei. Mezőgazda Kiadó, Budapest, pp. 50-52.

Niklfeld, H. (1973): Natürliche Vegetation. 1:2000000. - In: Atlas der Donauländer. Deuticke, Wien.

Pécsi, M. (ed.) (1989): Magyarország Nemzeti Atlasza. [National atlas of Hungary]. - MTA Földrajztudományi Kutató Intézete, Budapest, 396 pp.

Pócs, T. (1981): Magyarország növényföldrajzi beosztása. [Phytogeographical division of Hungary]. - In: Hortobágyi, T. and Simon, T. (eds): Növényföldrajz, társulástan és ökológia. Nemzeti Tankönyvkiadó, Budapest, pp. 120-155.

Rapaics, R. (ed.) (1927): Magyarország (csonka részének) életföldrajzi térképe. [Biogeographical map of "mangled Hungary"]. - Föld és Ember 7(1-2): melléklet [appendix].

Schmidt, D., Lengyel, A. and Szuromi, T. (2008): Flórakutatás a Pannonhalmi-dombságban 2003-2007 között. (Floristical research in Pannonhalma Hills between 2003 and 2007). - Kitaibelia 13(1): 189.

Soó, R. (1941): Grundzüge zur Pflanzengeographie Ungarns. - Földr. Közlem. 69: 51-80.

Soó, R. (1960): Magyarország új florisztikai-növényföldrajzi felosztása. [New floristicphytogeographic division of Hungary]. - MTA Biol. Csop. Közlem. 4: 43-70. 
Soó, R. (1961): Grundzüge zu einer neuen floristisch-zönologischen Pflanzengeographie Ungarns. - Acta Bot. Acad. Sci. Hung. 7: 147-174.

Soó, R. (1964): Magyarország florisztikai és cönológiai növényföldrajza. [Floristic and coenologic phytogeography of Hungary]. - In: Soó, R.: A magyar flóra és vegetáció rendszertani-növényföldrajzi kézikönyve I. Akadémiai Kiadó, Budapest, pp. 96-129.

Soós, L. (1934): Magyarország állatföldrajzi felosztása. [Zoogeographical division of Hungary]. - Állatt. Közlem. 31(1-2): 1-25.

Szabó, J., Pásztor, L. and Bakacsi, Zs. (2005): Egy országos, átnézetes, térbeli talajinformációs rendszer kiépítésének igényei, lehetősége és lépései. (Possibilities and development of a country-wide, spatial, soil-information system). - Agrokém. Talajtan 54: $41-58$.

Tuzson, J. (1910): Magyarország növényföldrajzi térképe Simonkai Lajos hagyatékából. [Phytogeographical map of Hungary from the heritage of Lajos Simonkai]. - Bot. Közlem. 9(6): 288-289.

Tuzson, J. (1911): Magyarország fejlődéstörténeti növényföldrajzának fóbb vonásai. Székfoglaló értekezés. [Main lines of the evolutionary phytogeography of Hungary]. Math. Termtud. Ért. 29(4): 558-589.

Várallyay, Gy. (1985): Magyarország 1:100000 méretarányú agrotopográfiai térképe. (Agrotopographical map of Hungary, 1:100,000). - Agrokém. Talajtan 34: 243-248.

Varga, Z. (1964): Magyarország állatföldrajzi beosztása a nagylepkefauna komponensei alapján. [Zoogeographical division of Hungary based on the components of the butterfly fauna]. - Rovartani Közlem. 17: 119-167.

Vojtkó, A. (2001): A Bükk hegység növényföldrajzi felosztása. [Phytogeographical division of the Bükk Mountains]. - In: Vojtkó, A. (ed.): A Bükk hegység flórája. Sorbus 2001 Kiadó, Eger, pp. 23-44.

Zólyomi, B. (1951): Magyarország flóratérképe. [Flora map of Hungary]. - In: Soó, R. and Jávorka, S.: A magyar növényvilág kézikönyve I-II. Akadémiai Kiadó, Bp., melléklet.

Zólyomi, B. (1967): Rekonstruált növénytakaró. [Reconstructed vegetation]. 1:1500000. - In: Radó, S. (ed.): Magyarország Nemzeti Atlasza. Kartográfiai Vállalat, Budapest, pp. 21, 31.

Zólyomi, B. (1989): Magyarország természetes növénytakarója. (Map of the potential natural vegetation of Hungary). - In: Pécsi, M. (ed.): Nemzeti Atlasz. Kartográfiai Vállalat, Budapest, p. 89. 